\title{
Foresighting for Inclusive Development
}

\section{Andersen, Allan Dahl; Andersen, Per Dannemand}

\section{Published in:}

Technological Forecasting and Social Change

Link to article, DOI:

10.1016/j.techfore.2016.06.007

Publication date:

2017

Document Version

Peer reviewed version

Link back to DTU Orbit

Citation (APA):

Andersen, A. D., \& Andersen, P. D. (2017). Foresighting for Inclusive Development. Technological Forecasting and Social Change, 119, 227-236. https://doi.org/10.1016/j.techfore.2016.06.007

\section{General rights}

Copyright and moral rights for the publications made accessible in the public portal are retained by the authors and/or other copyright owners and it is a condition of accessing publications that users recognise and abide by the legal requirements associated with these rights.

- Users may download and print one copy of any publication from the public portal for the purpose of private study or research.

- You may not further distribute the material or use it for any profit-making activity or commercial gain

- You may freely distribute the URL identifying the publication in the public portal

If you believe that this document breaches copyright please contact us providing details, and we will remove access to the work immediately and investigate your claim 


\title{
Foresighting for Inclusive Development
}

\author{
Allan Dahl Andersen \\ Centre for Technology, Innovation and Culture (TIK) \\ Oslo University, Norway \\ Email: adahlandersen@gmail.com
}

Per Dannemand Andersen

DTU Management Engineering

Technical University of Denmark

Email: pean@dtu.dk 
We propose that foresight can contribute to inclusive development by making innovation systems more inclusive. Processes of developing future oriented innovation policies are often unsuccessful and rarely inclusive. We conceptualize such processes as foresighting. We focus on how the ex-ante design of policymaking processes affects the actual process with a focus on inclusion, and we discuss how it affects policy effectiveness and innovation system transformation. Our argument is that processes of policymaking must be inclusive to affect and transform innovation systems because a set of distributed actors, rather than ministries and innovation agencies, is the gatekeepers of change. From this perspective, inclusion is a precondition rather than an obstacle for transformation. Based on the notion of innovation system foresight, we develop an analytical framework that we use to study design and processes in foresight cases in two emerging economies: Brazil and South Korea. We conclude that better systemic and innovation oriented foresight is needed to enhance inclusive development.

Keywords:

Inclusive development; foresight, innovation systems; innovation policy; emerging economies

Highlights:

- Experiences from foresight designs in Brazil and South Korea

- Foresight can help make innovation systems to be more inclusive

- Distributed actors are the gatekeepers of innovation system transformation

- Among social, industrial, and territorial inclusion we focus on industrial

- We need better systemic and innovation oriented foresight to enhance inclusive development 


\section{Introduction}

From the perspective of evolutionary economics, learning and innovation are the most important processes in development (Nelson 2008). Including people in learning and innovation activities is thus a central part of inclusive development. The extent and direction of innovation activities are strongly influenced by a set of social structures that we often refer to as innovation systems. Making such systems more inclusive will thus promote inclusive development. We propose here that foresight may help us bring about more inclusive innovation systems.

Ministries of finance, industry or science and technology in developing countries often produce ambitious plans and related innovation policies for strengthening and connecting science and technology (S\&T) and industry activities to support innovation systems. Too often, such strategic initiatives fail. We suggest that one important explanatory factor behind failed policies can be found in the design of the very process of generating them. We argue that the extent to which the process of developing future oriented innovation policy ${ }^{1}$ is inclusive has important consequences for its likelihood of having an effect ex post. We conceptualize the process developing strategic innovation policy as foresight. Foresight is an important and widely used instrument for future oriented policymaking and for "wiring up" innovation systems (Martin \& Johnston 1999).

Foresight has over the recent decade or more implemented a more systemic and evolutionary understanding of innovation. In earlier work, we have suggested 'innovation system foresight' (ISF) as a tentative framework that can bring forward this development (Andersen \& Andersen, 2014). ISF is a tool for strategically guiding innovation system (IS) transformations in desirable directions, e.g. towards more inclusivity. Nonetheless, such transformations are, we argue, feasible only if foresight design adheres to the basic ideas of ISF. These include a systemic understanding of innovation, which demands a focus on the particularities of the context wherein innovation takes place and relatively broad inclusion. Hence, our main proposition is that ISF can not only possibly ensure more inclusivity in innovation policymaking but also enhance the 'effectiveness' of it. From this perspective, inclusion is a precondition rather than an obstacle for transformation. To achieve transformations,

\footnotetext{
1 We refer to innovation policy in the "broad" sense (Lundvall \& Borrás 2005). Furthermore, we use the terms "strategic" and "future-oriented" innovation policy interchangeably.
} 
governments must build and institutionalize competences for inclusive public-private dialogue around innovation policy.

The effect of inclusion in innovation activities on development outcomes is an emergent research area (Heeks et al. 2014; Johnson \& Andersen 2012). The theme has hitherto largely been ignored in both innovation and development studies (Cozzens \& Sutz 2014). Most empirical research on inclusion and innovation focuses on micro-level processes (for example, grassroots or frugal innovations), but the importance of broader system structures (i.e., institutions) wherein the latter processes are embedded is widely acknowledged (Andersen \& Johnson, 2015; Cozzens \& Sutz, 2014). In this paper, we focus on structural features of innovation policymaking. We thus contribute to the former knowledge gap by outlining how foresight can make innovation policy, and in turn innovation systems, more inclusive. More precisely, our argument is that the conceptual understanding of innovation and foresight that, embedded in foresight design, guides the process of innovation policymaking to a large extent determine whether its output (e.g. growth plan) can be implemented. The idea to combine foresight and innovation systems to study inclusive development is novel, and it emerges from the authors' respective experience with innovation studies, technology foresight and development studies.

Although most research concerns the inclusion of poor and vulnerable communities, a recent initiative from the OECD broadens the notion of inclusion to encompass social, industrial, and territorial inclusion into innovation systems (OECD 2013). A central point is that although aiding the poor remains at the core of inclusive development, we must acknowledge important interdependencies between the different forms of inclusion. For example, including poor people in labour markets depends on the growth of heterogeneous firms, and the workplace is often a key arena for learning. The inclusion of poor people into learning activities (as education) can help firms succeed via better equipped workers. Additionally, firms remain the key drivers of inclusive development and the main actors for up-scaling and diffusing inclusive innovations (specific products and services). We focus on industrial inclusion and thereby also contribute to research on inclusive development by exploring this novel concept empirically.

The paper is both conceptually and empirically explorative. We propose that a certain type of foresight thinking — innovation system foresight - is particularly conducive to inclusive 
development. Using interviews and secondary data sources, we present indicative evidence from case studies in Brazil and South Korea.

Section 2 presents the conceptual linkages between foresight, inclusion and innovation system transformation. Section 3 presents our analytical framework and methods. Section 4 presents cases from Brazil and South Korea. Section 5 contains an analysis of the cases. Section 6 discusses the findings and concludes the paper.

\section{Foresight, innovation systems and inclusion}

\subsection{Inclusive and systemic policymaking}

It is widely recognized that neither a universal recipe for nor a general theory of policymaking for innovation exists (Ahlqvist et al. 2012). Nonetheless, policy and strategy development are increasingly being interpreted as a continuous, reflexive, distributed, and interactive learning process (Georghiou et al. 2008; Ahlqvist et al. 2012). Rodrik (2006, 2010) argues that in the global learning economy, there are no simple and universal paths to economic development. Therefore, any path is necessarily unclear ex ante, which makes systematic experimentation with policy and institutions the only sensible strategy.

The systemic and distributed character of innovation has implications for inclusion in the policymaking processes. It has been recognized that the effectiveness-here understood as the implementation of policies, which is indicated by behavioural changes in actors — of policy depends to a large extent on the involvement of a broad range of actors in addition to those formally in charge. Due to the complexity of the learning economy, policy formulation relies on the knowledge, experience and competence of different stakeholders. Because policymakers cannot be understood as perfectly informed social planners, distributed policymaking via the inclusion of key stakeholders emerges as a necessary and integral part of innovation policy. Experience shows that involving key stakeholders and the public in dialogue and decision-making processes is essential to making socially robust solutions for new technology (Gibbons 1999; Mallett 2013).

In this respect, policymaking is to a large extent about aligning expectations and building shared visions of the future that can enable the coordination of interdependent actors. Public policy thus plays a catalysing role in this perspective, which implies that the process of 
formulating innovation policy and the benefits related to it (process benefits) might be more important than actual tangible outputs, such as reports, list of priorities and regulation (product outputs) (Ahlqvist et al. 2012). Hence, broad inclusion has a strong instrumental value for innovation policy, and policymaking needs to be both systemic and participatory.

The direction of innovation policy development activities should not be understood as 'blind'. It is directed by the dominant vision of the future — of what a desirable future would be - and resolving what are identified as problems in that optic. The influence of the perception of the future on the direction of learning and innovation is strong, whether it is explicit or implicit. It is not possible to rationally invest in a business, study for a career, save money or even send our children to school without making some assumptions about the shape of the future-it is thus inherent to decision making (Wehrmeyer et al. 2003). The process of policy experimentation should be guided by a deep understanding of current problems and by a systematic understanding of what the future might be.

\subsection{Foresight}

Foresight is often understood as a dynamic and systemic planning tool with participatory and inclusive elements. It is an activity that aims to build medium to long term visions, aimed at influencing present day decisions and mobilizing joint actions (Miles 2008). The purpose of foresight is thus to imagine different futures and their consequences and, on that basis, to engage in informed decision making. It is perceived as a process where new insights emerge and capabilities are built rather than a tool for prediction. Foresight thus rests on two key assumptions: (i) that the future is not laid out (ii) and that decisions made and actions taken today can affect the future. Foresight often functions as a knowledge input to formal innovation policymaking (e.g., legislation) that goes on in ministries and parliament. However, the effect of foresight on actual policymaking is debated (Costa et al. 2008; Havas et al. 2010). One of the key aspects for successful impact of foresight on policymaking is actually to create strong public-private partnerships during the foresight process as well as the integration of stakeholders into foresight programs (Calof \& Smith 2010). In foresighting for inclusive development we put further emphasis on such inclusion of stakeholders. 


\subsection{Innovation system foresight}

Since the term was first suggested in the mid-1980s, foresight has been accepted as a field of practice in public policymaking (Irvine \& Martin 1984; Martin 2010). Foresight has been characterized by increasing conceptual broadening and diversity that reflects experimentation with and application of diverse rationales as foundation for foresight. It has become more participatory and complex and is applied at multiple levels across numerous sectors (Miles 2008).

Amidst this growing diversity, the notion of innovation system foresight (ISF) was formulated. ISF serves to re-accentuate and further explore the conceptual commonalities of foresight and innovation systems thinking in a context where explicitly innovation oriented foresight approaches are few. Moreover, ISF is formulated partly in response to a lack of theoretical underpinnings and analytical coherency in the area of foresight research, and partly to accommodate the changing perception of innovation and innovation policy from a linear to an evolutionary systems perspective (Andersen \& Andersen 2014). ISF is defined as a systemic, systematic, participatory, future-intelligence-gathering and medium to long term visionbuilding process aimed at present-day decisions and mobilizing joint actions with the purpose of transforming innovation systems in desirable directions, e.g. inclusivity or growth (Andersen \& Andersen, 2014). In contrast to previous foresight approaches, ISF explicitly focuses on the nexus between foresight and innovation system research. We argue that the tenets of ISF make it a useful tool for making innovation systems more inclusive.

A foresight can be described as consisting of three main phases: pre-foresight (design of foresight), foresighting (process of foresight) and post-foresight (implementation and dissemination of the outputs and outcomes of foresight), with each phase containing a number of steps, as seen from figure 1. In reality, the process is more iterative and contains several feedback loops, but for simplicity, these are not included in the illustration. ISF directly affects the pre-foresight phase, and due to interdependency between the phases, it indirectly affects the foresight and post-foresight phases. Below, we outline how ISF differs from foresight in general on four points (see more detail in Andersen \& Andersen, 2014).

(1) The goal of foresight. In the literature, several goals - or rationales - are mentioned such as setting priorities in S\&T, guiding innovation systems, shop window for competences, enrolling new actors in the S\&T debate, and network building (Barré \& Keenan 2008; Miles 
et al. 2008). However, we find that there exists a hierarchy among these goals. The primary goal of ISF is to 'strengthen' the innovation system in general. The aforementioned goals are seen as inputs to this primary goal.

(2) System boundaries. There seems to be no agreed-upon method for setting system boundaries in foresight exercises and thus classifying factors as external or internal. Boundary setting influences the choice of methodology, data collection and stakeholder involvement in subsequent steps in the foresight process. ISF suggests following the definition of an innovation system as the organizing principle for setting boundaries. The system is then defined to include "the elements and relationships which interact in the production, diffusion and use of new and economically useful knowledge" (Lundvall 1992). This principle for boundary setting can, in turn, be used for different settings including sectors, technologies, regions, and nations.

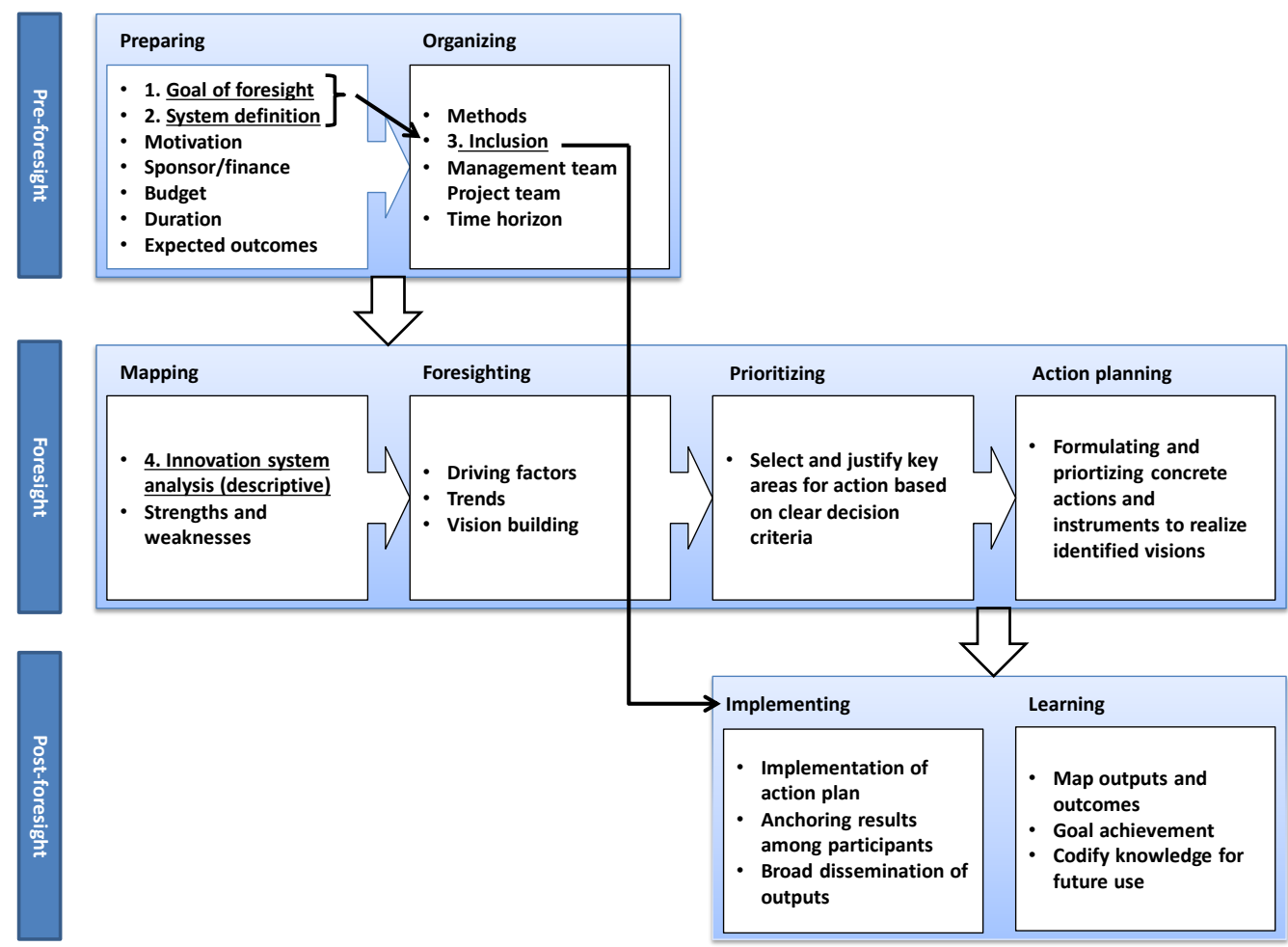

Figure 1: Phases and steps in foresight - based on Andersen and Rasmussen (2012)

(3) Inclusion. Innovation system transformation requires distributed policy, which in turn requires (meaningful) participation of all key stakeholders. This point is closely related to system definition. A systems approach will tend to favour broad inclusion/participation because actors are seen as the primary agents, or gatekeepers, of change. Despite being in 
principle a participatory policy instrument, the process of foresight can be more or less inclusive. Actually, so far, broader participation in foresight has been limited. Instead, the focus has been on expert groups. One can distinguish between narrow and broad foresight. Narrow foresight is based on a forecast tradition where only a few key experts are involved, whereas broad foresight includes a much wider set of stakeholders. Narrow foresight tends to assume that all new technology is beneficial and progressive, whereas broad foresight includes a discussion of the desirability, costs, benefits and direction of innovation (Loveridge 2005). ISF is, in other words, inclusive foresight. There is a crucial link between inclusion and the implementation of foresight results in the post-foresight phase, which is essential for the usefulness of the exercise. In this sense, the initial system definition and the identification and enrolment of key stakeholders partly define implementation possibilities (Calof \& Smith 2010). It reflects a systemic interdependency between pre- and post-foresight because if those actors that are required to change behaviour have not been included, there is little chance that they will act in accordance with the formulated plans (Cagnin, 2011). In general, for policy interventions to be implementable in practice they must "crowd-in" the intrinsic motivations actors have such that they perceive them as supportive (Ostrom 2005).

(4) Mapping the present. There is no widely agreed-upon method for analysing the present system situation. The quality of any foresight will depend on the quality of the mapping exercise because it will serve as a basis for the following foresighting steps. We suggest an innovation system framework for such analysis.

\subsection{Innovation system foresight and inclusive development}

There are many ways of defining inclusive development and so far no precise and broadly accepted definition of the term has emerged (Johnson \& Andersen 2012). In this paper, we emphasize two aspects of inclusive development. First, one can distinguish between passive and active inclusion. Passive inclusion refers to initiatives to reduce inequality through redistribution of assets ex-post an economic process. While this can certainly contribute to balance out some inequalities, it is unlikely to address the factors producing inequality in the first place. Active inclusion requires that actors take part in shaping the processes of political, social and economic change (Sen 2000). We emphasize this latter perspective and understand inclusive development as the reduction of inequality in voice, influence, and participation of otherwise excluded (groups of) actors. In this perspective, the notions of "inclusion" and 
"participation" in change processes are identical. ${ }^{2}$ Second, our focus is on inclusion in innovation and innovation policy processes. These are central but not sufficient for achieving inclusive development. Our attention to only one type of actors (firms) further limits our scope. We thus merely focus on one aspect of inclusive development.

Foresight adhering to the tenets of ISF as outlined above can potentially promote inclusiveness in innovation systems through multiple channels:

1. To manage, support and build interactive learning spaces. This involves supporting, reorienting and creating new networks and linkages within and across technologies, sectors and markets and around problem solving (Smits \& Kuhlmann 2004). These interactive learning spaces can aid communication, understanding and collaboration across boundaries, be they geographical, organizational or disciplinary in nature, and thereby increase understanding and build trust between participants. Consequently, they can improve policy implementation through increased transparency, legitimacy and ownership. (Barré \& Keenan 2008).

2. Stimulating the identification, articulation and translation of the needs of the poor into demand for knowledge. This is an often overlooked but critical component of successful interactive learning and innovation (Laestadius 1998). Hence, there is a need for spaces that can facilitate these activities across subsystems.

3. Capability building in participants and on a system level with a focus on enhancing responsiveness to change and on strategic thinking by developing language and practice for thinking about the future (Barré \& Keenan 2008).

4. Informing policy decision making processes, which concerns generating insights decision making regarding the dynamics of change, future challenges and options, along with new ideas, and transmitting them to policymakers (Costa et al. 2008).

5. Facilitating policy implementation via inclusion, which enhances the capability for change within a given field by building a common awareness of the current situation and future challenges (Costa et al. 2008).

6. Embedding participation in innovation policymaking. This corresponds to an institutionalization of ISF, which can facilitate the inclusion of civil society and industry

${ }^{2}$ Hence, we use the terms interchangeably in this paper. 
in the policymaking process, thereby improving its transparency, legitimacy and effectiveness (Costa et al. 2008).

It is important to note that these benefits are exclusively 'process benefits' that are not possible with limited inclusion (narrow participation). Because policy must be distributed and actors are seen as the primary agents of change, innovation system foresight must be 'inclusive' to be transformational. Moreover, ISF places particular emphasis on the micro foundations of the innovation system approach, which is interactive learning between users and producers (Johnson 2011). These actors require a shared vision to engage in successful interactive learning. Vision building can here be understood as bridging 'distances' (e.g. cognitive, cultural) between actors to ensure better communication. In this way, ISF can enhance the quality and quantity of couplings between actors in the economy, which augments the 'effectiveness' of innovation systems (Fagerberg et al. 2009). Additionally, ISF has the potential to strategically affect the direction of innovation activities through its function of vision building and influencing actors' behaviour. This led Georghiou (2007) to argue that inclusive forms of foresight may not only make successful innovation more likely but also shape the direction of innovation towards solutions to problems related to grand societal challenges such as sustainability, poverty, or exclusion.

\section{Analytical framework and methods}

The main line of argumentation in this paper, which is illustrated in figure 2 , is that to strategically include firms in learning and innovation, we must first include them in designing policies for innovation-led development. We suggest that one promising way of doing this is to further pursue the ideas embedded in ISF. However, inclusion is only one parameter in ISF. It is thus necessary but not sufficient for reorienting innovation systems. We operationalize the four points that distinguish ISF from foresight more generally. We propose that as the design of a foresight more strongly adheres to these points, its likelihood of succeeding in transformative change and development increases due to the process benefits accumulated. In the empirical analysis, we focus primarily on how foresight design affects the foresight process; see the dotted area at the bottom of figure 2. In the analysis, we thus compare how foresight design influences foresight processes in two cases and from that, we make tentative inferences about policy effectiveness. Our cases are embedded in a wider context that may 
influence our phenomenon of interest. Although such influences are beyond the scope of our paper, we will be attentive to the issue.

Figure 2: Degrees of ISF and innovation system transformation - analytical framework



We analyse two cases of sector foresight from Brazil and South Korea, respectively. The countries were chosen for four reasons. First, both have extensive foresight activities and programmes targeting innovation and development. Second, both countries struggle to support innovation system transformation using foresight and innovation policy. Third, both are emerging economies that hold many lessons for other developing countries. Fourth, the foresight cases differ greatly between the countries, which make them interesting for comparison. In the following sections, we analyse and compare foresight practice in an organization (South Korea) and one foresight exercise (Brazil). We compare these rather different cases by focusing on the analytical dimension of foresight design i.e. extracting the how the conceptualization of foresight influences foresight design (planning), and the subsequent foresight processes. The empirical material draws extensively on a technical report by Andersen, Andersen, Park, \& Cagnin (2014). 
The case analysis will contain three main elements. First, we present a selective description of the innovation policy context. Second, we describe the foresight environment and earlier experiences. These descriptive parts presented in section four constitute the context wherein the individual foresight cases unfold. The third part of the analysis is to assess ISF content in the design of selected foresights and how this relates to the foresight process. Our foresight cases focus on the level of industrial sectors embedded in a wider national foresight culture. We focus on the period from approximately 1990 to 2010 where foresight activities for innovation policy took hold. Our data consist of academic publications, foresight reports and eight interviews with main actors in Brazil and South Korea conducted in June and July 2012. See Table 2 in appendix. In the following sections, we use numerous abbreviations. An overview of these can be found in table 3 in the appendix.

\section{Case descriptions}

\subsection{Brazil}

\section{Policy for Innovation}

In the 1990s, initiatives on innovation policy were crowded out by strict macroeconomic policies. Governments abstained from proactive innovation policy which, instead, was left to the 'market forces'. In this period, the Ministry of Science and Technology (MCT) had marginal influence (Koeller \& Cassiolato 2009). Innovation policy gradually returned during the 2000s, but competences for public-private dialogue on policy development had deteriorated. To restore industrial policy, resources allocated to innovation activities (both public and private) increased significantly. ${ }^{3}$ In this context, foresight was seen as a tool for restoring such dialogue.

An important initiative was the Industrial, Technological and Foreign Trade Policy (PITCE) launched in 2004 by the Ministry for Development, Industry and Trade (MDIC). At the core of the PITCE was stimulating technological innovation and disseminating a pro-innovation discourse through the various ministries. This novel policy initiative lacked coordinating organizations and institutional support. Consequently, the government created the National Council for Industrial Development (CNDI) to support the formulation, implementation and

\footnotetext{
${ }^{3}$ In 2000, Brazil invested approximately USD 8,327 million in 'scientific and technological activities', which grew to USD 23,453.37 million by 2008 (1.43\% of GDP) (RICYT, 2010).
} 
monitoring of the PITCE. The CNDI aimed to give coherence to actions and proposals and to strengthen the dialogue between the public and the private sector on innovation policy. The Brazilian Agency for Industrial Development (ABDI) was created as an executive secretariat for the CNDI. In addition to contributing to policy implementation and monitoring, ABDI also functions as a strategic think tank that interacts with industry via institutionalized channels of communication with most Brazilian industries in the form of competitiveness forums, trade chambers, sectoral chambers and working groups (MDIC 2010). ABDI articulates and diffuses the interests of industry in the CNDI. The mission of ABDI is to develop strategic plans for industrial development by promoting investment, employment, innovation and competitiveness in Brazilian industry (ABDI 2012). ABDI occasionally engages in foresighting with the participation of industry to develop such plans. It is part of a continuous dialogue that has generated trust between all actors (Filho \& Cagnin 2012).

\section{Foresight experiences}

The first explicit foresight (national) in Brazil was Brazil 2020 (1998), which was the first real attempt at 'integrated governmental planning'. The foresight did not explicitly aim to produce guidelines and priorities for public investments, and it can best be understood as an early reflection exercise that has contributed to developing the capacity in Brazil for longterm thinking (Santos \& Filho 2007). The second foresight exercise was the Prospectar Programme (2000-2003), which was managed by the MCT, focused on science and technology trends and their potential effects on Brazilian industry and society. The programme achieved a remarkable mobilization of researchers (over 10,000), which helped raise awareness of Brazil's future challenges and interest in long-term thinking. Problem identification and formulation was the main outcome (Popper \& Medina 2008).

Nearly simultaneously, the MDIC launched the Brazilian Technology Foresight Program (2000) with support from UNIDO. The motivation was to assess future challenges and opportunities of sectors (production chains) of strategic importance with the goal of contributing to industrial competitiveness through technological innovation supported by public policies (Santos \& Filho 2007). Several reports were published from the exercise, but policymakers struggled to implement the results (MDIC 2002; Castro 2001). According to Aulicino \& Kruglianskas (2008), this was because the underlying foresight processes did not include important industrial actors. They conclude that the pre-foresight process must be more 
inclusive and involve the key stakeholders to improve their understanding of and participation in the process. In 2004, the Nucleus of Strategic Issues of the Presidency launched the foresight programme called Brazil 3 Moments project: 2007, 2015 and 2022. The programme aimed to define long-term national strategic objectives but was not particularly focused on innovation (Santos \& Filho 2007; Popper \& Medina 2008). It was created to build an inclusive dialogue between the State and the Brazilian society on the values, methods and desirable solutions for reaching strategic goals (Santos \& Filho 2007). From these foresight activities has emerged the insight that broad inclusion is increasingly important for policy and strategy impact.

\section{Foresight case description - Plano Estratégico Setorial}

In Brazil, we focus on a particularly interesting sectoral foresight programme called 'Plano Estratégico Setorial' (strategic sector plan - PES). It was managed in a collaboration between ABDI and the Center for Strategic Studies and Management in Science, Technology and Innovation (CGEE) between 2004 and 2008.

PES was launched under PICTE to analyse and support sector-specific needs and competitiveness in a production chain perspective with a 15-year time horizon (ABDI 2012). PES contained three steps. First, a panorama analysis (description of the current situation) was performed for each sector. Second, on the basis of the trends, the issues and perspectives relevant to a segment of the sector were identified. Third, building on the first two steps, a sector competitiveness agenda (roadmap) was developed to support the formulation and implementation of public policies to strengthen competitiveness and innovation (Arcuri 2009). PES was partly initiated and managed by the ABDI. It resulted in 11 sectoral foresights for sector development strategies that were used as inputs to the discussions in the CNDI. These foresights were in turn used to formulate the Productive Development Policy programme launched in 2008, the aim of which was to improve long-term competitiveness. The foresights were used as inputs to discussions with the private sector. ABDI contracted CGEE to carry out the foresights in PES. 


\subsection{South Korea}

\section{Policy for Innovation}

OECD has recently argued that South Korea faces a challenge of moving from a 'catching-up' to a 'creative' innovation system. South Korea has reached the technological frontier in several sectors (particularly ICT) and must now increasingly stimulate innovative and creative technological development (OECD 2009). One challenge is that innovation policy is primarily focused on technology-push strategies rather than the diffusion of knowledge and interactions among actors (systemic policy). Additionally, the innovation system tends to overly favour the incumbent sectors of ICT and machinery manufacturing. Hence, the development model of South Korea is changing. Its approach to innovation policy must also change (Oh 2011).

According to OECD, South Korea must develop a systematic and evolutionary approach to the promotion of innovation to support the dynamics and efficiency of innovation processes (2009). There is, in other words, a need for systemic policy tools for innovation required for achieving system transformation, which hinges on distributed innovation policy and inclusive processes, as argued by OECD (2009: 185): “clearly, governments alone cannot implement national innovation systems; the form and functioning of the latter tend to depend upon the actions of and linkages between a constellation of actors, both public and private".

Nonetheless, innovation policy in South Korea is hierarchical and centralized (Schlossstein \& Park 2006). Such top-down policy has been effective during the catching-up period but is now less suitable. Consequently, there is a growing need for inclusive innovation policy in South Korea. In this context, foresight at both national and sector levels has been an instrument for addressing the challenges outlined.

\section{Foresight experiences}

In South Korea, foresight is central to innovation policy, which is predominantly managed in the form of laws and national plans that coordinate policies and allocate resources to STI. These traditional policy instruments have been complemented and informed by development of national visions and roadmaps (OECD 2009). One of the earliest initiatives for spurring this transformation was the formulation of 'Vision 2025' in 1999, which involved several farreaching proposals. As a part of realizing Vision 2025, the government launched the 'Science and Technology Framework Law' in 2001. It aims at promoting S\&T more systematically by inter alia developing mid- and long-term strategies and implementation plans, improved rules 
for inter-ministerial coordination, and broad support for R\&D activities, S\&T agencies and an innovation-driven culture. Moreover, based on the Framework Law, the government formulated the first '5-Year Science and Technology Plan' and a 'National Technology Road Map', which were instruments for realizing Vision 2025. The first 5-year plan set out priorities for S\&T investment, national R\&D, and human resource development (MEST 2012). The law made it mandatory to carry out a national technological foresight as a basis for formulating the 5-year plans. The Korean Institute of Science and Technology Evaluation and Planning (KISTEP) manages these foresights (Park \& Son, 2010). Foresight is thus formally linked to innovation policy in South Korea (STEPI 2012).

In terms of foresight design, South Korea found inspiration in Japan for its first foresight in 1993. It was based on three rounds of Delphi surveys with thousands of experts. The focus was on identifying future key technologies without taking into account a social dimension. The second South Korean technology foresight was initiated in 1998. The design and methodology were similar to those of the first technology foresight (Schlossstein \& Park 2006). Schlossstein \& Park (2006) conclude that these first two national technology foresights failed as a result of the exclusion of key stakeholders in the South Korean national system of innovation, and weak government commitment.

The third South Korean technology foresight was initiated in 2003. It built on the previous two but also contained new methodological elements. It went beyond S\&T and R\&D priority setting and set out to match future societal needs and appropriate technological developments. Although the matching exercise was a novelty in South Korea, the Delphi technique remained the main tool. The foresight consisted of three phases, and the general public (1,000 persons) participated only briefly in the first phase. Thus, the exercise was dominated by experts that were asked about the future needs of society. The move towards a more 'inclusive' methodology made the foresight more transparent and useful for policymakers and resulted in the direct policy uptake of foresight results for the first time in South Korea (Schlossstein \& Park 2006). According to Park \& Son (2010), this third technology foresight reflects a movement, although limited, towards a systemic understanding of foresight and innovation due to the increased focus on social aspects and broader inclusion (policymakers, social scientists and citizens were involved, in comparison with earlier reliance on only natural scientists and engineers) that was intended to overcome the limited impact of the previous foresights (Park \& Son 2010). In addition to the national technology foresights, 'technology 
road mapping' is widespread in South Korea. It is the main form of foresight at the sector level in South Korea. Several private actors and think tanks use it as strategic and analytical tool.

In general, foresight activities are confined to being exercises made within ministries with participation of academics and experts. This characteristic complicates impact and system transformation. Currently, the legacy of top-down policymaking and S\&T bias in innovation policy are barriers for developing a systemic, inclusive and innovation-oriented type of foresight. The national technology foresights and most technology road mapping activities tend to be non-systemic, technology-focused, non-inclusive, hierarchical and centralized. In accordance, Park \& Son (2006) argue that although there are variations in methodology, foresight activities in South Korea are oriented towards product outputs such as scenarios, Delphi survey results, and future technology lists, whereas attention to process outcomes such as building collective visions and strategies and sharing knowledge is low.

\section{Foresight case description - Korean Institute for Advancement of Technology}

The main public policy foresight actors in South Korea are the Ministry of Education, Science and Technology (MEST) and the Ministry of Knowledge Economy (MKE). Each ministry has several affiliated research agencies that perform foresight activities to varying extents. The MKE's mission is to achieve future-oriented industrial development, to strengthen the competitiveness of key industries, and to promote new growth engines (OECD 2009). These tasks involve strategy development and implementation, to which foresight is central. The MEST is concerned with setting priorities for the long-term direction of S\&T development. Hence, whereas the MEST is oriented towards S\&T (non-industry focus), MKE is closer to industry and more concerned with innovation. In practice, it implies that the MEST focuses on long-run S\&T priorities, and MKE focuses on technology development in the short and medium run (KIAT 2012a).

We focus on the MKE, under which two agencies, the Korea Institute for Advancement of Technology (KIAT) and the Korean Evaluation Institute of Industrial Technology (KEIT), manage the majority. Here, we focus on the KIAT, which is the main actor. Foresight in MKE primarily takes the form of technology road mapping, which is currently performed yearly for 35 sectors, covering nearly all sectors in South Korea; of those, KIAT is responsible for 20 
(KIAT 2012a). KIAT aims to develop and coordinate sectoral innovation systems and to facilitate interactive innovation processes among key actors (KIAT 2012b). The conceptual model used to manage foresight in KIAT has an explicit focus on technology development. The framework contains an analysis of the sector's strategic environment (phase 1), an analysis of sector-internal issues (phase 2), setting goals on basis of SWOT analysis (phases 3 and 4), and developing a strategy plan (phase 5) (KIAT, 2012c; Kim, 2012).

\section{Case analysis}

Despite the similarities of challenges faced in terms of foresight and innovation in the two countries, the case studies reveal some interesting differences. Table 1 summarizes the case studies and our assessment of them which we return to in the concluding section.

Table 1: Summing up case studies

Plano Estratégico Setorial Korean Institute for Advancement of Technology

\begin{tabular}{|c|c|c|c|c|}
\hline & Characteristic & $\begin{array}{c}\text { ISF } \\
\text { "Score"* }\end{array}$ & Characteristic & $\begin{array}{c}\text { ISF } \\
\text { "Score"* }\end{array}$ \\
\hline $\begin{array}{l}\frac{\hbar}{0} \\
\frac{0}{0} \\
\frac{1}{0} \\
\frac{0}{0} \\
\frac{0}{\pi} \\
\frac{0}{0}\end{array}$ & $\begin{array}{l}\text { Effective industrial policy; } \\
\text { transforming industrial system } \\
\text { System transformation focus is } \\
\text { important. It makes you identify } \\
\text { actors as gatekeepers. }\end{array}$ & $(++)$ & $\begin{array}{l}\text { New industries and technologies by setting } \\
\text { priority lists for investment in S\&T rather than } \\
\text { generating change } \\
\text { This type of expert-based screening for } \\
\text { future technologies must be seen as only } \\
\text { one input to actual foresight and not end } \\
\text { product }\end{array}$ & $(+)$ \\
\hline 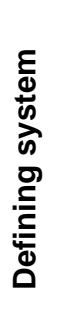 & $\begin{array}{l}\text { Ad hoc and weak innovation focus } \\
\text { but with systemic understanding } \\
\text { of performance } \\
\text { Illustrate that absence of explicit } \\
\text { method for delimitating system of } \\
\text { interest leads to ad hoc solutions }\end{array}$ & $(++)$ & $\begin{array}{l}\text { MKE decides sector boundaries via industry } \\
\text { codes. } \\
\text { Non-systemic understanding of performance } \\
\text { and innovation } \\
\text { Illustrate that absence of explicit method for } \\
\text { delimitating system of interest leads to ad } \\
\text { hoc solutions }\end{array}$ & $(+)$ \\
\hline $\begin{array}{l}\text { 음 } \\
\text { 을 } \\
\text { 음 }\end{array}$ & $\begin{array}{l}\text { Broad inclusion } \\
\text { Illustrate necessity of enrolling } \\
\text { industry and how to do it (short- } \\
\text { vs. long-term trade-off, trust) }\end{array}$ & $(+++)$ & $\begin{array}{l}\text { Narrow inclusion, expert-based Delphi } \\
700 \text { experts organized yearly in expert } \\
\text { groups. Nonetheless, top-down, expert- } \\
\text { driven and technology-focused method for } \\
\text { strategy development without broader } \\
\text { participation of stakeholders from the } \\
\text { Innovation System. } \\
\text { Shows necessity of enrolling industry though } \\
\text { by negative example. }\end{array}$ & $(+)$ \\
\hline
\end{tabular}




\begin{tabular}{|c|c|c|c|c|}
\hline \multirow{2}{*}{ 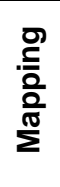 } & \multirow{2}{*}{$\begin{array}{l}\text { Ad hoc design based on SWOT } \\
\text { and STEEPV but with significant } \\
\text { systemic features }\end{array}$} & \multirow[t]{2}{*}{$(++)$} & $\begin{array}{l}\text { Standard foresight instruments such as } \\
\text { SWOT, STEEP, patents/scientific papers }\end{array}$ & \multirow{2}{*}{$(+)$} \\
\hline & & & $\begin{array}{l}\text { Ad hoc and S\&T focused (linear } \\
\text { understanding of innovation) }\end{array}$ & \\
\hline
\end{tabular}

* The number of $(+)$ indicates the degree of similarity with ISF; $(+)$ weak, $(++)$ moderate, $(+++)$ strong

\subsection{Goal of foresight}

\section{Plano Estratégico Setorial}

The Plano Estratégico Setorial was intended to increase competitiveness, but more notably, ABDI and CGEE acknowledged the distributed character of industrial and innovation policy, particularly of strategy development for the longer term. This reflects the idea that industrial performance is a systemic phenomenon and that the success of (innovation) system transformation hinges on the acceptance from key stakeholders. From this perspective, topdown policy is thus insufficient. Industrial actors must be enrolled in the strategydevelopment process. PES thus goes beyond both setting research agendas and expert-based foresights to focus on realizing structural change via inclusive processes.

\section{Korean Institute for Advancement of Technology}

The goal of foresight activities in KIAT is derived from the overall visions of the MKE, which, as mentioned, pivots around the creation of new industries, competitiveness and productivity (KIAT 2012a). However, KIAT suffers from the institutional structure of being delivery agencies for MKE in the sense that neither of them is much concerned with preforesight or post-foresight phases but merely performs the foresighting exercise. Their objectives are given by the MKE, which expects only a foresight report. This is an institutional weakness from the perspective of innovation system foresight.

\subsection{System boundaries}

\section{Plano Estratégico Setorial}

ABDI initially selected industries to be analysed. Each sector foresight had a steering committee with representatives from all stakeholders, including BNDES, MCT, FINEP, sectoral organizations (national level industry associations), CGEE, ABDI, and others. Committees decided guidelines and followed the process closely. Committees decided industry boundaries and who would be relevant actors to include (Campanhola 2012). In the pre-foresight phase, ABDI insisted on using private business consultants to avoid CGEE's 
usual reliance on only university researchers. Consultants would be more pragmatic and focus more on 'market aspects', it was believed (Campanhola 2012). ABDI wanted to reorient CGEE towards a more industrially inclusive approach to foresight. Thus, there was no systematic methodology or underlying theory for setting boundaries. Nonetheless, the negotiation process reflects that ABDI insisted on avoiding an (top-down) expert based foresight.

\section{Korean Institute for Advancement of Technology}

KIAT does not have an explicit methodology for setting sector boundaries (Kim 2012). MKE decides such boundaries, often via industry codes (KIAT 2012a). This type of boundary setting rarely captures all important actors and relationships because innovation systems per definition cross standard industry classifications (Carlsson et al. 2002).

\subsection{Inclusion}

\section{Plano Estratégico Setorial}

The identification and enrolment of actors to participate in foresights was a crucial aspect of the PES studies. ABDI carefully chose key stakeholders from each industrial sector to be part of the project. ABDI's major goal was to persuade and to gain commitments from the committee representatives who could help organize the sector while improving its global competitiveness (Nehme et al., 2011: p. 5-6). The process was complicated, though. Firms insisted on solving short-term problems regarding interest rates and infrastructure and were not interested in or accustomed to long-term strategic thinking. ABDI succeeded due to a mix of factors.

First, ABDI invested significant resources in gradually trying to convince them (and government officials) about the usefulness of foresight via training and workshops. Second, simultaneously with the foresights, ABDI launched a number of consultancy projects focusing on short-term problem solving for industries. Seen in the total budget of the PES, these shortterm investments were insignificant, but they reflected a compromise between short- and long-term issues. These projects were used as 'bait' for industry commitment and made industrial actors experienced that they had influence, which in turn earned ABDI and PES legitimacy (Alvarez 2012). 
In addition, two context factors influenced the situation. First, ABDI was created to fill a vacuum in industrial policy in Brazil, and together with other policies (e.g., the PITCE), it reflects the determination in the government to pursue economic development through industrial policies that should pivot around science and technology. Industry perceived the latter as a business-friendly agenda and as a window of opportunity for actually influencing the political agenda (Alvarez 2012). Second, as a new organization, ABDI was determined and eager to prove itself by committing industry to programmes focusing on long-term policy and development strategies instead of indulging industry's obsession with short-term problems (Alvarez 2012). Moreover, according to ABDI Director Clayton Campanhola (2012), ABDI had a 'good name', i.e., is an actor respected and trusted by industry.

Hence, PES attained broad inclusion from industrial actors to facilitate industry transformation. Although it does not appear explicitly from our data, we may say that the design of PES had strong links between the pre-foresight and post-foresight phases. The ABDI/CNDI's mandate ensured political awareness and the extensive inclusion of industry actors facilitated their cooperation.

\section{Korean Institute for Advancement of Technology}

The number of persons participating in the KIAT's technology road mapping has been increasing. Now, approximately 700 experts participate in the 35 yearly mapping exercises. They are organized in expert groups consisting of approximately 20 persons each and come equally from universities, research organizations and industry (KIAT 2012a). However, according to Professor Karpsoo Kim, the increasing number does not change the fact that technology road mapping is generally a top-down method for strategy development, whereas foresight is a bottom-up method (Kim 2012). According to Kim, the KIAT's technology road mapping is essentially expert-driven and technology-focused without any broader inclusion of stakeholders.

\subsection{Mapping the system}

\section{Plano Estratégico Setorial}

Mapping the system created challenges for CGEE because sectors differed significantly, forcing CGEE to develop its own sector foresight model (Filho \& Cagnin 2012). It looks at each sector in six dimensions (general views) of society (Market, Social, Economic, 
Technological, Innovation, Competitive Strategies). The external and general trends are combined with a sector-specific analysis, where the focus is put on new players, main competitor countries and leader companies in the production chain. The production chain analysis looks at talent, infrastructure, investments, policy and institutions, design, and other 'specific' dimensions. It furthermore emphasizes the relationships between suppliers, producers and users in the chain as important for understanding needs (Nehme et al. 2011). The dimensions are chosen based on SWOT, STEEPV, or general experience. Although CGEE ad-hoc model is not linked to innovation system thinking, it reflects a systemic approach to both foresight and innovation.

\section{Korean Institute for Advancement of Technology}

There is no overarching theoretically anchored method for mapping the sectors (Kim 2012). The models illustrated apply standard foresight instruments such as SWOT, STEEP, patent analysis and value chain analysis. Moreover, a poor definition of system boundaries (section 5.2.2) complicates the mapping task. Reliance on quantitative standard indicators further inhibits mapping of innovation system.

\section{Discussion and concluding remarks}

The Plano Estratégico Setorial and previous foresight activities in Brazil can be seen as attempts to develop systemic innovation policy tools and to institutionalize them. The main lesson from PES is that systemic and inclusive foresight design generates inclusive policymaking processes that, in turn, increase the likelihood of significant policy impact. The successful inclusion of industrial actors is an interesting feature of PES. It is a general challenge for foresight to achieve this. We can draw five lessons from PES on this topic.

First, meaningful inclusion requires that industry representatives have knowledge of foresight and strategic innovation policy and consider it important, which implies training and dialogue. ABDI and CGEE organized training in the pre-foresight phase. Second, PES indicates that trust and dialogue between industry and government is a premise for enrolment and in turn meaningful participation. Industry must also be convinced that there is a real opportunity for influence. Third, a unique feature of PES was the management of trade-offs between shortterm problem solving and strategy development for the longer term. These three points all concern the inclusion of firms that initially wanted to be excluded. Fourth, during PES, CGEE 
experienced that firms changed perception of the project from disbelief to engagement. Hence, included actors learned new things during the processes. Fifth, PES indicates that both the institutionalized dialogue that ABDI had with industries and the dialogue taking place during PES were very important for identifying and articulating the needs of industries and for building trust.

PES was an experiment in identifying and formulating future needs for 11 industries. The companies alone would not have initiated such an experiment (Filho \& Cagnin 2012). ABDI thus functioned as a 'bridging organization' (see Boon, Moors, Kuhlmann, \& Smits, 2011) between industry, government and research. Such organizations seem indispensable when going beyond expert-based foresight. PES indicates that a continuous public-private dialogue about what constitutes current problems and a desirable future is a central part of managing innovation system transformation. On basis of our analysis, we evaluate the foresight design of PES to be reasonably similar to what we have identified as ISF; see table 1.

The design of foresight in KIAT seems to be primarily top-down, expert based, not theorybased, short term, product oriented, technology focused, and non-systemic. In this context, it is interesting to observe that KIAT identifies the poor diffusion of results, a weak industry impact, and the analysis of contextual factors as their main challenges. KIAT tries to diffuse results through hearings, meetings and engagement with industry, but the impact remains weak (KIAT 2012c; KIAT 2012a). Moving towards a systemic, inclusive and innovationoriented foresight style might alleviate the KIAT's challenges. A potential barrier for directly including more diverse actors can be found in South Korea's industrial structure. According to Sarpoo Kim, the multinational enterprises (Chaebols) are too strong to be bothered with what KIAT and MKE do, whereas the small and medium-sized enterprises (SMEs) are too weak to benefit from the results (Kim 2012). According to the KIAT, it is difficult to establish contact with industry, particularly SMEs. South Korea does not have capable industry associations (potential bridging organizations). Most of them have only 4-5 employees and are weak in terms of resources and capabilities (KIAT 2012a). In contrast to the PES case, there seems to be a lack of 'bridging organizations' such as ABDI and representatives for industrial actors that are able to proactively participate in foresights. The KIAT's foresight design and associated policymaking processes are not very inclusive and are thus far from the ideas of ISF; see table 1. Hence, by negative example, the KIAT's foresight activities suggest the same conclusion as PES, which is that foresight has potential as an inclusive and systemic 
innovation policy tool. This potential is exploited only when foresight is designed according to the tenets of ISF. This is because foresight (and innovation policy, more generally) must be inclusive to be transformational, which implies that the actors in the system of innovation are the principal agents of change- - the gatekeepers, so to say.

This conclusion lends support to the broader propositions of this paper, i.e., including (often uninterested) firms in learning and innovation activities requires that they first be included in collective public-private strategy development processes leading to innovation and development strategies to feel ownership of policies, to have influence on them, and to understand and learn about them. Moving towards such practices in innovation policymaking is one way of making innovation systems more inclusive and thus to promote inclusive development. Accepting the argument implies that governments should invest in inclusive public-private dialogue about future oriented innovation and development policies guided by a systemic understanding of innovation. Moreover, governments should focus more on the process benefits of inclusion and support the formation of bridging organizations in industry.

National investment priorities in innovation, which significantly affect the direction of innovation and thus the transformation of IS, are often selected in a relatively top-down manner. Its principal methodology is expert based working groups (with academic bias) and questionnaires surveying thousands of experts. The so-called linear model of innovation informs the underlying logic and perception of innovation, which is a problematic practice because we know that innovation is predominantly a systemic phenomenon. We have argued here that innovation system informed type of foresight can support better decision making in and the impact of such investments. This is particularly true in developing economies, where innovation systems are often fragmented (Szogs et al. 2011). Such countries are in need of systemic, forward looking and inclusive tools for 'wiring up' and transforming their embryonic systems of innovation. This paper constitutes a first tentative step towards finding a way forward. To build on and further explore this potential requires more conceptual work and empirical studies in developing countries. In terms of foresight techniques, we have kept to the simple dichotomy of inclusive, bottom-up versus non-inclusive, top-down categories. To move towards practical advice for foresight practitioners we need to start considering whether new techniques are needed to approach the insights of ISF. 


\section{Acknowledgements}

The study behind this paper was funded by an internal grant at the Technical University of

Denmark (DTU). The elaboration of the paper was partly carried out at Oslo University as a part of a project funded by Norwegian Research Council. We are grateful for the support of these institutions.

\section{References}

ABDI, 2012. Brazilian Agency for Industrial Development. Available at: http://www.abdi.com.br/Paginas/Default.aspx.

Ahlqvist, T., Valovirta, V. \& Loikkanen, T., 2012. Innovation policy roadmapping as a systemic instrument for forward-looking policy design. Science and Public Policy, 39(2), pp.178-190.

Alvarez, R., 2012. International Affairs Manager, ABDI, Interview, Brasilia, 6/6. Brazilian Agency for Industrial Development.

Andersen, A.D. et al., 2014. Exploring Sector Innovation System Foresight in Brazil and Korea: Competencies for Innovation System Transformation, Danish Technical University (DTU), Management Engineering, Kongens Lyngby, DK.

Andersen, A.D. \& Andersen, P.D., 2014. Innovation System Foresight. Technological Forecasting and Social Change, 88, pp.276-286.

Andersen, A.D. \& Johnson, B., 2015. Low carbon development and inclusive innovation systems. Innovation and Development, 5(2).

Andersen, P.D. \& Rasmussen, B., 2012. Fremsyn: Metoder, praksis og erfaringer, Danish Agency for Science, Technology and Innovation, Mnistry of Science, Innovation and Higher Education.

Arcuri, R.B., 2009. Plano de Trabalho 2010 (ABDI work plan 2010), Brasilia.

Aulicino, A.L. \& Kruglianskas, I., 2008. Foresight development and implementation effectiveness: lessons from the Brazilian experience. In Third International Seville Seminar on Future-Oriented Technology Analysis: Impacts and implications for policy and decision-making. Sevilla.

Barré, R. \& Keenan, M., 2008. Revisiting Foresight Rationales: What Lessons from the Social Sciences and Humanities? In C. Cagnin et al., eds. Future-Oriented Technology Analysis - strategic Intelligence for an Innovative Economy. Springer.

Boon, W.P.C.C. et al., 2011. Demand articulation in emerging technologies: Intermediary user organisations as co-producers? Research Policy, 40(2), pp.242-252.

Cagnin, C., 2011. Aspects to consider when designing foresight processes. In Foresight International Seminar: from theory to practice. Brasilia: CGEE.

Calof, J. \& Smith, J.E., 2010. Critical success factors for government-led foresight. Science and Public Policy, 37(1), pp.31-40.

Campanhola, C., 2012. Director, ABDI, Interview, Brasilia, 6/6. Brazilian Agency for Industrial Development.

Carlsson, B. et al., 2002. Innovation systems: analytical and methodological issues. Research policy, 31, pp.233-245.

Castro, A.M.G. de, 2001. Prospecção de cadeias produtivas e gestão da informação. Transinformação, 
$13(2)$.

Costa, O. Da, Warnke, P. \& Cagnin, C., 2008. The impact of foresight on policy-making: Insights from the FORLEARN mutual learning process. Technology Analysis \& Strategic Management, pp.1-20.

Cozzens, S. \& Sutz, J., 2014. Innovation in informal settings: reflections and proposals for a research agenda. Innovation and Development, 4(1), pp.5-31.

Fagerberg, J., Mowery, D.C. \& Verspagen, B., 2009. The evolution of Norway's national innovation system. Science and Public Policy, 36(6), pp.431-444.

Filho, L.F. \& Cagnin, C., 2012. CGEE, Interview, Brasilia, 4/6. Lelio Fellows Filho and Cristiano Cagnin are Senior Foresight Managers and researchers at CGEE.

Georghiou, L., 2007. Future of foresighting for economic development. In UNIDO Expert Group Meeting on the Future of Technology Foresight. Vienna.

Georghiou, L. et al., 2008. The Handbook of Technology Foresight, Cheltenham, UK: Edward Elgar Publishing.

Gibbons, M., 1999. Science's new social contract with society. Nature, 402.

Havas, A., Schartinger, D. \& Weber, M., 2010. The impact of foresight on innovation policy-making: recent experiences and future perspectives. Research Evaluation, 19(2), pp.91-104. Available at: http://openurl.ingenta.com/content/xref?genre=article\&issn=09582029\&volume $=19 \&$ issue $=2 \&$ spage $=91$ [Accessed March 12, 2012] .

Heeks, R., Foster, C. \& Nugroho, Y., 2014. New models of inclusive innovation for development. Innovation and Development, 4(2), pp.175-185.

Irvine, J. \& Martin, B., 1984. Foresight in science: picking the winners, Pinter London.

Johnson, B., 2011. From user-producer relations to the learning economy. Science and Public Policy, 38(9), pp.703-711.

Johnson, B. \& Andersen, A.D., 2012. Learning, Innovation and Inclusive Development - New perspectives on economic development strategy and development aid, Aalborg University Press.

KIAT, 2012a. Interview, Yeong Cheol Seok, KIAT Vice President, Department of technology strategy, July 16 th.

KIAT, 2012b. Korea Institute for Advancement of Technology. Available at: https://www.kiat.or.kr/site/main/index/index002.jsp.

KIAT, 2012c. Personal communication, Kee Nyeong Lee, Technology Planning Team, Team director.

Kim, K., 2012. Interview, July 11th, Professor in Innovation, KAIST.

Koeller, P. \& Cassiolato, J.E., 2009. Achievements and shortcomings of Brazil's innovation policies'. In J. E. Cassiolato \& V. Vitorino, eds. BRICS and development alternatives. Anthem Press.

Laestadius, S., 1998. The relevance of science and technology indicators: the case of pulp and paper. Research Policy, 27(4), pp.385-395.

Loveridge, D., 2005. Inclusive foresight. Foresight, 7(3), pp.31-47.

Lundvall, B.-Å. ed., 1992. National Systems of Innovation - Toward a Theory of Innovation and Interactive Learning, London: Pinter.

Lundvall, B.-Å. \& Borrás, S., 2005. Science, technology and innovation policy. In J. Fagerberg \& D. C. Mowery, eds. The Oxford handbook of innovation. Oxford University Press Oxford.

Mallett, A., 2013. Technology cooperation for sustainable energy: a review of pathways. Wiley Interdisciplinary Reviews: Energy and Environment, 2(2), pp.234-250. 
Martin, B., 2010. The origins of the concept of "foresight" in science and technology: An insider's perspective. Technological Forecasting and Social Change, 77(9), pp.1438-1447.

Martin, B.R. \& Johnston, R., 1999. Technology foresight for wiring up the national innovation system: experiences in Britain, Australia, and New Zealand. Technological Forecasting and Social Change, 60(1), pp.37-54.

MDIC, 2002. Estudo prospectivo da cadeia produtiva da construção civil: produção e comercialização de unidades habitacionais, Secretaria de tecnologia industrial, Brasilia.

MDIC, 2010. Ministry of Development, Industry and International Trade. Available at: http://www.mdic.gov.br/.

MEST, 2012. Ministry of Education, Science and Technology. Available at: http://english.mest.go.kr/enMain.do.

Miles, I., 2008. From Futures to Foresight. In L. Georghiou et al., eds. The Handbook Of Technology Foresight: Concepts and Practice. Edward Elgar Pub.

Miles, I. et al., 2008. The Many Faces of Foresight. In L. Georghiou et al., eds. The Handbook Of Technology Foresight: Concepts and Practice. Cheltenham, UK: Edward Elgar, pp. 3-23.

Nehme, C.C. et al., 2011. A foresight method for enhancing competitiveness of Brazilian industrial sectors. In The Annual Conference of the World Future Society, Vancouver, BC, Canada.

Nelson, R., 2008. Economic Development from the Perspective of Evolutionary Economic Theory. Oxford Development Studies, 36(1), pp.9-21.

OECD, 2013. Knowledge and Innovation for Inclusive Development, Paris.

OECD, 2009. OECD Reviews of Innovation Policy: Korea, Paris.

Oh, D., 2011. Dynamic History of Korean Science \& Technology, KISTEP, Seoul, Korea.

Ostrom, E., 2005. Policies that Crowd Out Reciprocity and Collective Action. In H. Gintis et al., eds. Moral Sentiments and Material Interests: The Foundations of Cooperation in Economic Life. MIT Press, pp. 253-277.

Park, B. \& Son, S., 2006. Korean technology foresight for science and technology policy making. In Second International Seville Seminar on Future-Oriented Technology Analysis: Impact of FTA Approaches on Policy and Decision-Making. Sevilla, pp. 1-19.

Park, B. \& Son, S.H., 2010. Korean Technology Foresight for national S\&T planning. International Journal of Foresight and Innovation Policy, 6(1/2/3), p.166.

Popper, R. \& Medina, J., 2008. Foresight in Latin America. In L. Georghiou et al., eds. The Handbook Of Technology Foresight: Concepts and Practice. Cheltenham: Edward Elgar, pp. 256-286.

RICYT, 2010. The Network on Science and Technology Indicators. Available at: http://www.ricyt.org/.

Rodrik, D., 2010. Diagnostics before prescription. The Journal of Economic Perspectives, 24(3), pp.3344.

Rodrik, D., 2006. Goodbye Washington Consensus, Hello Washington Confusion? A Review of the World Bank's Economic Growth in the 1990s: Learning from a Decade of Reform. Journal of Economic Literature, 44(4), pp.973-987.

Santos, D.M. \& Filho, L.F., 2007. The role of foresight experience in the promotion of Brazil's national innovation system. In Technology Foresight Summit 2007, Water Productivity in the Industry, 27-29 September. Budapest, Hungary.

Schlossstein, D. \& Park, B., 2006. Comparing recent technology foresight studies in Korea and China: towards foresight-minded governments? Foresight, 8(6), pp.48-70. 
Sen, A., 2000. Social exclusion: Concept, application, and scrutiny, Office of Environment and Social Development, Asian Development Bank.

Smits, R. \& Kuhlmann, S., 2004. The rise of systemic instruments in innovation policy. International Journal of Foresight and Innovation Policy, 1(1/2), pp.4-32.

STEPI, 2012. Interview, July 10th, Byeongwon Park, Leader of Future Strategy Team, STEPI and former Director of Technology Foresight Center, KISTEP.

Szogs, A., Cummings, A. \& Chaminade, C., 2011. Building systems of innovation in less developed countries : the role of intermediate organizations supporting interactions in Tanzania and El Salvador. Innovation and Development, 1(2), pp.283-302.

Wehrmeyer, W., Clayton, A. \& Lum, K., 2003. Foresighting for Development. Greener Management International, (37), pp.24-36.

\section{Appendix}

Table 2: Overview of interviews

\begin{tabular}{|c|c|c|}
\hline Name & When (2012) & Where \\
\hline $\begin{array}{l}\text { Lèlio Fellows Filho } \\
\text { Senior Foresight Manager and researcher } \\
\text { Cristiano Cagnin } \\
\text { Senior Foresight Manager and researcher }\end{array}$ & June 4 & CGEE, Brasilia \\
\hline $\begin{array}{l}\text { Roberto Alvarez } \\
\text { International Affairs Manager }\end{array}$ & June 6 & ABDI, Brasilia \\
\hline $\begin{array}{l}\text { Clayton Campanhola } \\
\text { Director (at the time) }\end{array}$ & June 6 & ABDI, Brasilia \\
\hline $\begin{array}{l}\text { Byeongwon Park } \\
\text { Future Strategy Team } \\
\text { Research fellow } \\
\text { Former Director } \\
\text { Technology Foresight Center } \\
\text { KISTEP }\end{array}$ & July 10 & STEPI, Seoul \\
\hline $\begin{array}{l}\text { Karpsoo Kim, } \\
\text { Professor, KAIST }\end{array}$ & July 11 & KAIST, Daejon \\
\hline $\begin{array}{l}\text { Moonjung Choi } \\
\text { Director of Technology Foresight Division } \\
\text { Office of Future Strategy }\end{array}$ & July 12 & KISTEP, Seoul \\
\hline $\begin{array}{l}\text { Ilgu Cho } \\
\text { Technology Planning Team Leader }\end{array}$ & July 13 & KEIT, Daejon \\
\hline $\begin{array}{l}\text { Yeong Cheol Seok } \\
\text { Department of Technology Strategy } \\
\text { KIAT Vice President } \\
\text { Kee Nyeong Lee } \\
\text { Technology Planning Team } \\
\text { Team director }\end{array}$ & July 16 & KIAT, Seoul \\
\hline
\end{tabular}

Table 3: List of abbreviations

Abbreviation Full name

Country 


\begin{tabular}{|l|l|l|}
\hline ABDI & Brazilian Agency for Industrial Development & Brazil \\
\hline CGEE & $\begin{array}{l}\text { Center for Strategic Studies and Management in Science, Technology \& } \\
\text { Innovation }\end{array}$ & Brazil \\
\hline CNDI & National Council for Industrial Development & Brazil \\
\hline KAIST & Korea Advanced Institute of Science and Technology & South Korea \\
\hline KEIT & Korean Evaluation Institute of Industrial Technology & South Korea \\
\hline KIAT & Korea Institute for Advancement of Technology & South Korea \\
\hline KISTEP & Korean Institute of Science and Technology Evaluation and Planning & South Korea \\
\hline MCT & Ministry of Science and Technology & Brazil \\
\hline MDIC & Ministry for Development, Industry and Trade & Brazil \\
\hline MEST & Ministry of Education, Science and Technology & South Korea \\
\hline MKE & Ministry of Knowledge Economy & South Korea \\
\hline PES & Plano Estratégico Setorial' (strategic sector plan) & Brazil \\
\hline PITCE & Industrial, Technological and Foreign Trade Policy & Brazil \\
\hline STEPI & Science and Technology Policy Institute & South Korea \\
\hline
\end{tabular}

